\title{
Profil Literasi Keuangan Mahasiswa Penerima Beasiswa Bidikmisi
}

\author{
Romi Kurniadi*, Almasdi Syahza, dan Suarman \\ Universitas Riau
}

\begin{abstract}
Abstrak Kajian ini bertujuan untuk menganalisis literasi keuangan mahasiswa penerima Beasiswa Bidikmisi. Penelitian ini dilaksanakan di Pekanbaru dengan subjek penelitian mahasiswa penerima Beasiswa Bidikmisi Fakultas Keguruan dan Ilmu Pendidikan Universitas Riau. Penelitian ini merupakan jenis penelitian survei yang bertujuan memaparkan literasi keuangan mahasiswa penerima Beasiswa Bidikmisi. Sampel penelitian ini sebanyak 178 mahasiswa yang diambil dari populasi sebanyak 630 mahasiswa dengan teknik Cochran sampling. Data dikoleksi melalui kuesioner berupa tes yang dianalisis secara deskriptif. Hasil kajian menunjukkan bahwa literasi keuangan mahasiswa penerima Beasiswa Bidikmisi Fakultas Keguruan dan Ilmu Pendidikan Universitas Riau berada pada kategori literate dengan persentase jawaban benar 64,61\%.
\end{abstract}

Kata kunci: literasi; keuangan; beasiswa; Bidikmisi; cochran sampling

\begin{abstract}
This study aims to analyze the financial literacy of Bidikmisi Scholarship recipient students. This research was conducted in Pekanbaru with the research subject of the Bidikmisi Scholarship recipient students of the University of Riau Teacher Training and Education Faculty. This research is a type of survey research that aims to explain the financial literacy of Bidikmisi Scholarship recipient students. The sample of this study was 178 students taken from a population of 630 students using the Cochran sampling technique. Data collected through questionnaires in the form of tests that are analyzed descriptively. The results of the study indicate that the financial literacy of students receiving the Bidikmisi Scholarship in the Teacher Training and Education Faculty of the University of Riau is in the literate category with the percentage of correct answers $64.61 \%$.
\end{abstract}

Keywords: literacy; finance; scholarship; Bidikmisi; cochran sampling

JEL Classification: A1O; A13; A14

* Penulis koresponden

E-mail: romikurniadi3@gmail.com 


\section{PENDAHULUAN}

Memiliki literasi keuangan menjadi kebutuhan vital agar manusia memperoleh kesejahteraan dari sumber daya yang ada. Literasi keuangan yang baik juga bisa meningkatkan besaran pendapatan. Literasi keuangan diharapkan tidak hanya mampu meningkatkan kesejahteraan masyarakat, namun juga dapat membantu mengurangi angka kemiskinan. Lebih lanjut literasi keuangan dijelaskan sebagai kemampuan untuk mengelola pengeluaran sesuai dengan pemasukan, keputusan untuk berinvestasi, besaran tabungan dalam satu periode pendapatan, serta perencanaan yang matang dalam keputusan kredit.

Dalam jangka panjang, ketika kesejahteraan meningkat, literasi keuangan tetap akan diperlukan. Bukan hanya untuk menyelesaikan penggunaan keuangan sebagai usaha pemenuhan kebutuhan sehari-hari, namun juga sudah berkembang pada peningkatan kesejahteraan. Literasi keuangan pada tahap ini dibutuhkan dalam rangka memutuskan jenis, bentuk, tempat, dan waktu untuk berinvestasi, mendapatkan jaminan keamanan dari asuransi, serta pengelolaan kredit untuk memperoleh penghasilan berkesinambungan.

Kesejahteraan keuangan dapat diperoleh dari ketepatan pengalokasian uang yang dimiliki. Pengalokasian keuangan ini memerlukan pengetahuan, sikap dan implementasi yang dikenal sebagai literasi finansial. Sejauh mana pengetahuan, sikap dan implementasi seseorang dalam mengelola keuangan dikenal dengan literasi finansial (Widayati, 2012). Hal ini menunjukkan bahwa literasi keuangan perlu untuk dicermati.

Mahasiswa memiliki kendala dalam mengelola keuangan pribadi dikarenakan kebanyakan mahasiswa baru pertama kali mengelola keuangan secara mandiri ketika berada di bangku perguruan tinggi. Menurut Sabri dalam Margaretha dan Pambudhi (2015) mengemukakan bahwa bagi sebagian mahasiswa, pengelolaan keuangan secara pribadi tanpa ada campur tangan dan pengawasan orang tua secara penuh baru dilakukan ketika berada di bangku perkuliahan. Mengatur pengeluaran dimulai dari membayar sewa kos, membeli buku pelajaran, pembuatan tugas, kebutuhan transportasi dan makanan dengan menyesuaikan sumber daya keuangan yang diterima dari orang tua menjadi hal yang baru.

Sebagaimana telah dipaparkan sebelumnya, bahwa sumber daya uang yang besar tidak menjadi jaminan kesejahteraan jika tidak dikelola dengan baik. Maka situasi ini akan semakin buruk jika sumber daya uang yang dikelola sangat terbatas. Mahasiswa yang memiliki latar belakang keluarga dengan kemampuan ekonomi menengah ke bawah tentu harus memiliki kecakapan lebih dalam mengelola sumber daya uang yang terbatas ini.

Mahasiswa dengan status latar belakang ekonomi kurang mampu namun berprestasi diberi kesempatan untuk memperoleh beasiswa, salah satunya adalah beasiswa Bidikmisi. Sekalipun mahasiswa telah mendapat beasiswa Bidikmisi, bukan berarti sumber daya uang yang dimiliki dalam jumlah besar. Artinya, mahasiswa Bidikmisi perlu memiliki kemampuan manajemen keuangan yang baik.

Secara umum, mahasiswa Bidikmisi memperoleh bantuan biaya hidup (living cost) sebesar Rp.600.000,- perbulan. Sistem pembayaran untuk Universitas Riau dibayarkan dua kali dalam satu semester, atau 1 kali per 3 bulan. Jika ditambah dengan uang tunjangan dari orang tua sebesar Rp.600.000,- (jumlah maksimum pendapatan orang tua dibagi dengan jumlah tanggungan), maka jumlah pendapatan mahasiswa Bidikmisi sebesar Rp.1.200.000,-. Artinya, mahasiswa Bidikmisi bisa saja 
memperoleh pendapatan lebih rendah dari jumlah total tersebut. Ini adalah jumlah yang sangat kecil untuk memenuhi kebutuhan sehari-hari.

Sandra (2017) dalam penelitiannya tentang pola perilaku konsumsi mahasiswa Bidimisi menemukan bahwa rata-rata penerima Bidikmisi Universitas Riau memiliki tingkat pendapatan per-bulan Rp.1.000.000,- sampai dengan Rp.1.200.000,-. Selain itu, dalam penelitian ini ditemukan bahwa tingkat pendapatan mempengaruhi pola perilaku konsumsi sebesar 5,2\%, artinya, sekalipun pendapatan rendah, perilaku konsumsi tidak bias terkontrol dengan baik. Pada saat penelitian ditemukan beberapa mahasiswa membeli kebutuhan non prioritas.

Pengetahuan keuangan sangat berperan penting dalam mengatasi fenomena rendahnya kemampuan manajemen keuangan pribadi. Tsalitsa (2016) dalam penelitiannya menemukan bahwa literasi keuangan dan penghasilan memiliki pengaruh positif terhadap keputusan pengambilan kredit. Mawo dkk. (2017) menemukan bahwa literasi keuangan berpengaruh negatif terhadap perilaku konsumtif siswa. Maka, semakin baik literasi keuangan seseorang, maka akan semakin bijak dalam melakukan kegiatan konsumsi.

Buruknya manajemen keuangan pribadi mahasiswa penerima Beasiswa Bidikmisi menuntut kepemilikan literasi keuangan yang baik. Oleh karena itu, pada penelitian ini akan dikaji profil literasi keuangan mahasiswa Bidikmisi Program Studi Pendidikan Ekonomi Fakultas Keguruan dan IImu Pendidikan Universitas Riau.

Tujuan dari penelitian ini adalah dalam rangka menganalisis literasi keuangan mahasiswa Penerima Beasiswa Bidikmisi. Untuk mencapai tujuan tersebut, dibutuhkan informasi terkait dengan pengetahuan keuangan mahasiswa penerima beasiswa Bidikmisi dilihat dari gender, jurusan, dan indeks prestasi kumulatif.

\section{KAJIAN PUSTAKA}

\section{Literasi Keuangan}

Literasi dalam arti luas meliputi pemahaman (pengetahuan tentang kata, simbol, dan operasi hitung) dan penggunaan (kemampuan membaca, menulis, dan menghitung) dari bahan yang diprosakan, dokumen, dan informasi kuantitatif (Huston, 2010). Penerapan konsep literasi di atas pada bidang keuangan mengartikan bahwa literasi keuangan berfokus pada proses memahami informasi keuangan, memahami bacaan dan kemampuan berhitung yang berkaitan dengan keuangan. Huston (2010) mendefinisikan literasi keuangan sebagai proses mengukur seberapa baik individu dapat memahami dan menggunakan informasi keuangan pribadi. Huston mengkonseptualisasikan literasi keuangan pada dua dimensi, yaitu dimensi pemahaman (pengetahuan mengenai keuangan pribadi) dan dimensi penggunaan (penerapan konsep dan produk keuangan pribadi).

Berdasarkan penelitian yang telah ada, Remund (2010) mendefinisikan literasi keuangan ke dalam lima kelompok, yaitu: 1) pengetahuan konsep keuangan; 2) kemampuan mengkomunikasikan konsep keuangan; 3) kemampuan mengatur keuangan pribadi; 4) kemampuan membuat keputusan finansial yang tepat; dan 5) kepercayaan diri dalam membuat perencanaan masa depan yang efektif untuk memenuhi kebutuhan keuangan di masa depan. Organization for Economic Cooperation and Development (2012) mendefinisikan literasi keuangan sebagai pengetahuan dan pemahaman mengenai konsep dan risiko keuangan, kemampuan, motivasi dan kepercayaan dalam menerapkan pengetahuan dan pemahaman untuk 
membuat keputusan finansial yang efektif, sehingga dapat memperbaiki kesejahteraan individu dan masyarakat menjadi lebih baik.

Otoritas Jasa Keuangan (2014) menyatakan bahwa literasi keuangan merupakan rangkaian proses atau aktivitas untuk meningkatkan pengetahuan, keterampilan konsumen dan masyarakat luas sehingga mereka mampu mengelola keuangan dengan lebih baik, sesuai dengan apa yang mereka butuhkan dan memberikan manfaat.

Beberapa pengertian literasi keuangan di atas dapat disimpulkan bahwa literasi keuangan merupakan pengetahuan dan pemahaman mengenai pengelolaan keuangan pribadi untuk dapat diaplikasikan dalam kehidupan sehari-hari sehingga mampu memperbaiki kesejahteraan hidup menjadi lebih baik. Literasi keuangan tidak hanya berfokus pada pemahaman masyarakat mengenai konsep-konsep keuangan, tetapi penggunaan konsep-konsep keuangan pada kehidupan sehari-hari.

\section{Aspek Literasi Keuangan}

Programme for International Student Assessment (dalam Organization for Economic Cooperation and Development, 2014) membagi pengetahuan keuangan ke dalam empat ruang lingkup pembelajaran. Ruang lingkup literasi keuangan menurut PISA (a) Uang dan Transaksi (Money and Transaction), (b) Perencanaan dan manajemen keuangan (Planning and Managing Finance), (c) Risiko dan Manfaat (Risk and Reward), dan (d) Lanskap keuangan (Financial Landscape). Menurut Nababan dan Sadalia (2014) terdapat beberapa indikator penting dalam literasi keuangan, yaitu (a) basic personal finance, (b) money management, (c) credit dan debt management, dan (d) saving and investment.

Mengenai isi dari pengetahuan keuangan tersebut, Huston (2010) mengidentifikasi hal-hal berikut sebagai bagian dari pengetahuan keuangan, yaitu (a) Dasar-dasar keuangan pribadi, yang meliputi nilai waktu uang, daya beli, konsep akuntansi keuangan, (b) Peminjaman, yaitu penggunaan sumber daya keuangan masa depan untuk saat ini melalui penggunaan kartu kredit, hutang jangka panjang, atau hipotek, (c) Penyimpanan/investasi, menyimpan sumber daya yang dimiliki saat ini untuk kebutuhan masa depan melalui penggunaan rekening penyimpanan, saham, obligasi atau pembiayaan yang sejenis, dan (d) Perlindungan sumber daya, yaitu melalui produk asuransi atau teknik manajemen risiko lainnya.

Pada penelitian ini indikator yang akan digunakan dalam mengukur pengetahuan keuangan mahasiswa adalah (a) pengetahuan umum keuangan, yaitu terkait dengan manfaat pengetahuan keuangan; perhitungan tingkat bunga sederhana; bunga majemuk; dan inflasi, (b) manajemen keuangan, terkait dengan pendapatan; sumber pendapatan; instrumen keuangan yang berkaitan dengan pengeluaran; penganggaran; dan karakteristik ATM, (c) utang dan kredit meliputi kelayakan kredit; biaya peminjaman; kartu kredit, (d) tabungan dan investasi terkait dengan lembaga penjamin simpanan; deposito; obligasi; saham, serta (e) manajemen risiko yang terkait dengan asuransi.

\section{Faktor yang Mempengaruhi Literasi Keuangan}

Menurut Huston (2010) terdapat beberapa faktor yang dapat mempengaruhi kebiasaan finansial seperti ekonomi, keluarga, teman, kemampuan kognitif, kebiasaan, masyarakat dan kelembagaan. Margaretha dan Pambudhi (2015) dalam penelitiannya tentang tingkat literasi keuangan menemukan bahwa terdapat pengaruh antara jenis kelamin, usia, IPK, dan pendapatan orang tua terhadap tingkat literasi keuangan mahasiswa. 
Faktor-faktor yang mempengaruhi literasi keuangan menurut Widayati (2012) adalah (a) status sosial ekonomi masyarakat, (b) status sikap, (c) pendidikan pengelolaan uang keluarga, (d) pembelajaran di perguruan tinggi, dan (e) pendapatan.

Widayati (2012) menjelaskan pembelajaran di perguruan tinggi sangat berperan penting dalam proses pembentukan literasi finansial mahasiswa. Mahasiswa tinggal di lingkungan ekonomi yang beragam dan kompleks sehingga peningkatan kebutuhan pendidikan keuangan sangat diperlukan. Pembelajaran yang efektif dan efisien akan membantu mahasiswa memiliki kemampuan memahami, menilai, dan bertindak dalam kepentingan keuangan mereka. Adanya pengetahuan yang baik sejak dini diharapkan mahasiswa dapat memiliki kehidupan yang sejahtera di masa yang akan mendatang.

Dapat disimpulkan bahwa faktor yang mempengaruhi literasi keuangan seseorang meliputi (a) pendidikan keuangan di keluarga, (b) kemampuan kognitif, (c) masyarakat, (d) kelembagaan, (e) jenis kelamin, (f) usia, (g) pendapatan, dan (h) latar belakang pendidikan formal.

\section{METODE}

Penelitian ini merupakan jenis penelitian survei yang dilaksanakan di Pekanbaru dengan subjek penelitian mahasiswa Fakultas Keguruan dan IImu Pendidikan Universitas Riau. Teknik pengambilan sampel menggunakan metode Cochran diperoleh sampel yaitu sebanyak 178 orang dengan proporsi $20 \%$ laki-laki dan $80 \%$ perempuan. Jumlah sampel ini dialokasikan ke beberapa program studi yang ada di Fakultas Keguruan dan IImu Pendidikan Universitas Riau yaitu Pendidikan Matematika, Pendidikan Kimia, Pendidikan Biologi, dan Pendidikan Fisika, Pendidikan Ekonomi, Pendidikan Sejarah, PPKn, PLS, PGSD, BK, Kepelatihan, dan Penjaskesrek.

Data yang digunakan adalah data primer. Sumber data primer diperoleh jawaban atas tes literasi keuangan responden, serta perilaku keuangan responden. Pengumpulan data dilakukan melalui kuesioner. Kuesioner nantinya akan disusun dalam dua bentuk, yaitu tes dan angket. Teknik analisis data dilakukan dengan terlebih dahulu mengidentifikasi dan mengategorikan tingkat literasi keuangan mahasiswa. Hasil tes yang ditabulasikan dengan memberikan poin 1 untuk jawaban yang benar, dan memberikan nilai 0 untuk jawaban yang salah. Analisis statistik deskriptif bertujuan untuk menjelaskan tentang gambaran yang diteliti melalui data sampel tanpa melakukan analisis dan membuat kesimpulan yang berlaku umum. Hasil jawaban yang benar lalu dipersentasekan untuk kemudian dikelompokkan dalam kategori penilaian yang disajikan pada Tabel 1.

Tabel 1. Kategori Penilaian Literasi Keuangan

\begin{tabular}{ll}
\hline Persentase & Kategori \\
\hline More than $80 \%$ & $\begin{array}{l}\text { Memiliki pengetahuan yang tinggi mengenai literasi } \\
\text { keuangan (well literate) }\end{array}$ \\
$60 \%$ to $79 \%$ & $\begin{array}{l}\text { Memiliki pengetahuan yang sedang mengenai literasi } \\
\text { keuangan (literate) } \\
\text { Bellow 60\% }\end{array}$ \\
$\begin{array}{l}\text { Memiliki pengetahuan yang rendah mengenai literasi } \\
\text { keuangan (unliterate) }\end{array}$ \\
\hline
\end{tabular}

Sumber: menurut Chen and Vulpe (dalam Margaretha dan Pambudhi, 2015) 


\section{HASIL DAN PEMBAHASAN}

\section{Gambaran Umum Responden}

Literasi keuangan sebagai sebuah bentuk kepemilikan pengetahuan dan kemampuan pengaplikasian atas instrumen keuangan yang ada perlu untuk dimiliki dalam rangka memaksimalkan sumber daya uang mencapai kesejahteraan. Mahasiswa penerima beasiswa Bidikimisi sebagai salah satu unsur mahasiswa yang memiliki keterbatasan sumber daya keuangan tentu menjadi prioritas utama memiliki literasi keuangan yang baik. Penelitian ini melibatkan 178 mahasiswa penerima beasiswa Bidikmisi se-Fakultas Keguruan dan IImu Pendidikan Universitas Riau yang terdiri dari 16 Program Studi.

Mahasiswa Bidikmisi dituntut untuk mencapai prestasi tertentu agar kontrak beasiswa Bidikmisinya dapat terus berlanjut, salah satunya adalah memperoleh Indeks Prestasi Kumulatif (IPK) minimal 2,5 untuk bidang IPA dan 2,75 untuk jurusan sosial dan humaniora. Data IPK mahasiswa penerima beasiswa Bidikmisi Fakultas keguruan dan Ilmu pendidikan disajikan pada Gambar 1.

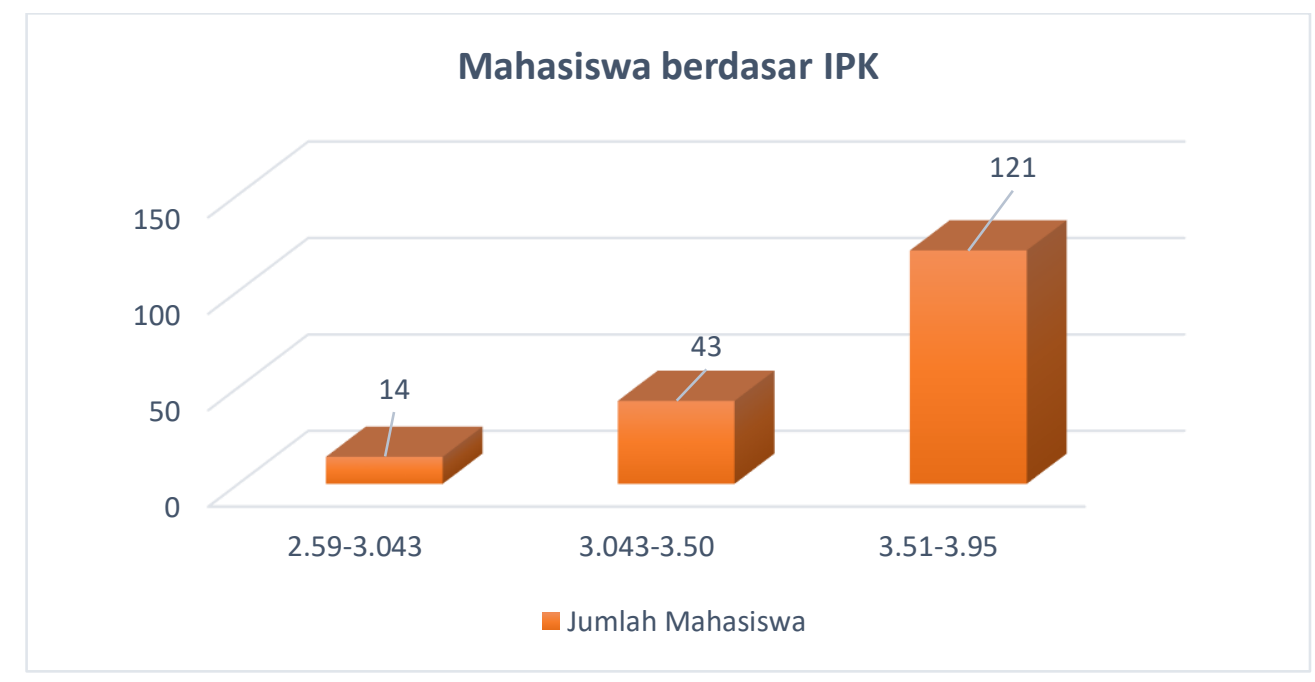

Gambar 1. Indeks Prestasi Kumulatif Mahasiswa Penerima Beasiswa Bidikmisi

Fakultas Keguruan dan IImu Pendidikan Universitas Riau

Pada penelitian ini juga dikumpulkan data penghasilan mahasiswa Bidikmisi di FKIP Universitas Riau. Komponen penghasilan yang didata meliputi living cost dari beasiswa Bidikmisi, kiriman dari orang tua, serta pendapatan lain yang diperoleh dari pekerjaan mahasiswa jika ada. Data penghasilan mahasiswa disajikan pada Gambar 2.

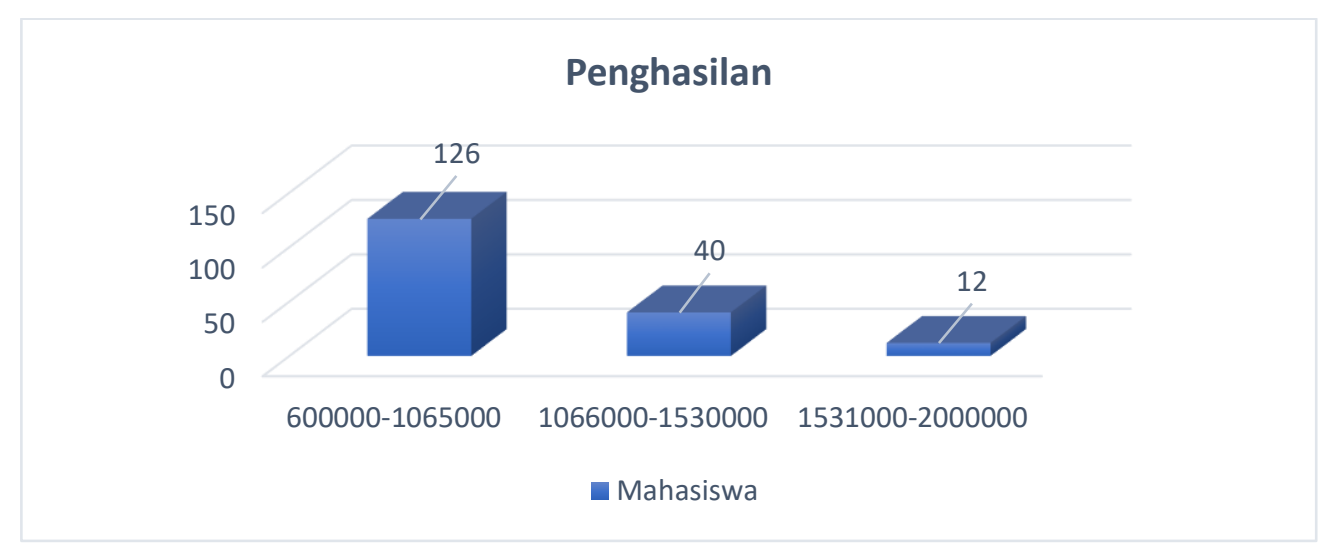


Gambar 2. Penghasilan Mahasiswa Penerima Beasiswa Bidikmisi Fakultas Keguruan dan IImu Pendidikan Universitas Riau

\section{Tingkat Literasi Keuangan}

Penelitian ini melihat literasi keuangan dari indikator pengetahuan keuangan dan perilaku keuangan. Pengetahuan keuangan mahasiswa penerima Beasiswa Bidikmisi Fakultas Keguruan dan IImu Pendidikan dikategorikan dalam tiga kategori, yaitu kategori (a) well literate, (b) literate, dan (c) unliterate. Pengetahuan keuangan secara umum disajikan pada Gambar 3.

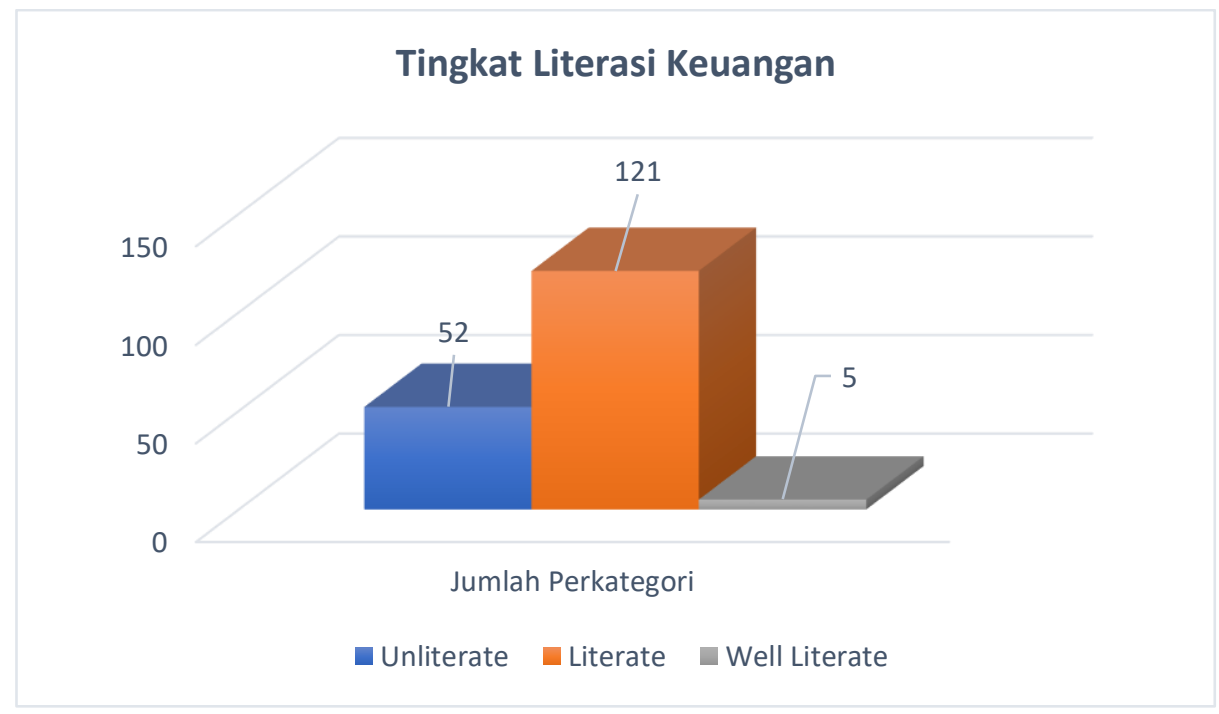

Gambar 3. Tingkat Literasi Keuangan Mahasiswa Penerima Beasiswa Bidikmisi Fakultas Keguruan dan IImu Pendidikan Universitas Riau

Secara keseluruhan pengetahuan keuangan mahasiswa penerima beasiswa Bidikmisi FKIP Universitas Riau berada pada kategori literate dengan persentase jawaban benar $64,61 \%$. Jika dilihat berdasar kategori pengetahuan keuangannya mahasiswa yang memiliki pengetahuan kategori well literate hanya 2,8\%, kategori literate sebesar $67,9 \%$, dan kategori unliterate $29,2 \%$. Dapat dilihat bahwa sebagian besar mahasiswa memiliki pengetahuan keuangan dalam kategori literate, artinya masih pengetahuan keuangannya masih berada pada kategori sedang. Masih banyak mahasiswa yang memiliki pengetahuan keuangan yang buruk yaitu berada pada kategori unliterate.

\section{Pengetahuan Keuangan Berdasarkan Jenis Kelamin}

Beberapa kajian menunjukkan bahwa gender menjadi salah satu hal yang mempengaruhi pengetahuan keuangan. Pada penelitian ini jumlah mahasiswa lakilaki yang dijadikan sampel adalah sebanyak 36 mahasiswa, dan mahasiswa perempuan sebanyak 142 mahasiswa. Data pengetahuan keuangan mahasiswa berdasarkan gender disajikan pada Gambar 4. 




Gambar 4. Pengetahuan Keuangan berdasarkan Gender

Pengetahuan keuangan mahasiswa laki-laki secara umum berada pada kategori literate dengan persentase $61,63 \%$. Mahasiswa laki-laki yang pengetahuannya berada pada kategori unliterate sebanyak $37,5 \%$ dan sebanyak $62,5 \%$ berada pada kategori literate. Pengetahuan keuangan mahasiswa perempuan secara umum berada pada ketegori literate dengan persentase jawaban benar $63,16 \%$. Untuk mahasiswa perempuan sebanyak $26,81 \%$ mahasiswa pengetahuan keuangan berada pada kategori unliterate, $69,56 \%$ berada pada kategori literate, dan $3,62 \%$ berada pada kategori well literate.

Jika dilihat dari hasil analisis statistik deskriptif, terlihat ada perbedaan persentase jawaban benar dari tes pengetahuan yang telah dilakukan kepada mahasiswa laki-laki dan perempuan. Mahasiswa perempuan memperoleh persentase jawaban benar secara keseluruhan lebih besar dibanding mahasiswa lakilaki. Mahasiswa perempuan persentase jawaban benarnya mencapai 63,16\%, sedangkan mahasiswa laki-laki persentase jawaban benarnya $61,63 \%$. Sekalipun berbeda, namun tingkat perbedaannya tidak signifikan yang dibuktikan dengan hasil pengujian dengan metode independent sample test.

Hasil ini memang berbeda dengan beberapa hasil kajian sebelumnya. Dalam hal ini perlu dilihat kembali bahwa salah satu pembentuk pengetahuan adalah pengalaman. Syahza (2014) pengetahuan (knowledge) adalah pembentukan pemikiran asosiatif yang menghubungkan atau menjalin sebuah pikiran dengan kenyataan atau dengan pikiran lain berdasarkan pengalaman yang berulang-ulang tanpa pemahaman mengenai sebab akibat (kausalitas) yang hakiki dan universal. Pendapat tersebut dikuatkan dengan pendapat Scott (dalam Robb dan Woodyard, 2012) bahwa pengetahuan keuangan dapat diperoleh dari pendidikan formal dan sumber-sumber informal. Pendidikan formal ini seperti program sekolah tinggi atau kuliah, seminar, dan kelas pelatihan di luar sekolah. Sedangkan sumber-sumber informal dapat diperoleh dari lingkungan sekitar, seperti dari orang tua, teman, dan rekan kerja, maupun yang berasal dari pengalaman sendiri. Berdasar pada pendapat tersebut, maka fenomena tidak signifikannya perbedaan pengetahuan keuangan antara mahasiswa laki-laki dan mahasiswa perempuan dapat dijawab dengan teori ini.

Pada era mobile ini, semua orang memiliki kesempatan yang sama untuk memperoleh akses instrumen keuangan untuk melakukan transaksi keuangan 
semisal belanja online. Mahasiswa laki-laki dan perempuan memiliki akses dan kesempatan yang sama dalam kegiatan belanja melalui situs online yang sangat memungkinkan untuk menggunakan berbagai instrumen keuangan. Bahkan penggunaan instrumen berupa kartu kredit, kartu debit, dan e-money pun sudah menjadi fenomena yang dianggap biasa oleh mahasiswa.

Pengelaman yang sama terbuka bagi mahasiswa laki-laki maupun mahasiswa perempuan inilah yang menjadikan keduanya memperoleh pengetahuan keuangan yang relatif sama. Ditambah dengan kepemilikan sumber daya uang yang juga relatif sama, maka akses mahasiswa untuk berbelanja dan mengakses instrumeninstrumen keuangan pun juga menjadi relatif seragam. Hal inilah yang menyokong pendapat bahwa tidak terdapat perbedaan pengetahuan keuangan yang signifikan antara mahasiswa laki-laki dan mahasiswa perempuan.

Tidak signifikannya perbedaan pengetahuan keuangan ditinjau dari sudut gender ini juga didukung oleh penelitian yang dilakukan oleh Rita dan Pesudo (2014). Dalam kajian yang dilakukan oleh Rita dan Pesudo juga ditemukan bahwa jenis kelamin tidak mempengaruhi pengetahuan keuangan secara signifikan. Hal ini sejalan juga dengan penelitian Irman (2018) yang menunjukkan bahwa tidak ada pengaruh jenis kelamin terhadap pengetahuan keuangan seseorang.

\section{Pengetahuan Keuangan berdasarkan Jurusan}

Latar belakang pendidikan menjadi salah satu faktor yang menentukan pengetahuan keuangan seseorang dalam beberapa kajian. Orang-orang dengan latar pendidikan sosial ekonomi disinyalir memiliki pengetahuan keuangan yang lebih baik dibanding dengan yang berasal dari bidang non sosial ekonomi. Untuk itu, pengetahuan keuangan juga dilihat dari latar pendidikan yang dibedakan dalam beberapa program studi. Pengetahuan keuangan mahasiswa penerima Beasiswa di Fakultas Keguruan dan Ilmu Pendidikan Universitas Riau disajikan pada Gambar 5.



Gambar 5. Pengetahuan Keuangan Berdasarkan Jurusan

Di Fakultas Keguruan dan IImu Pendidikan Universitas Riau terdapat lima jurusan dengan enam belas program studi. Berdasar data yang telah diperoleh, seluruh program studi pengetahuan keuangannya berada pada kategori literate, yaitu 
degan persentase jawaban benar di atas $60 \%$. Jurusan Ilmu Pendidikan Sosial yang terdiri dari program studi Pendidikan Ekonomi, Pendidikan Sejarah, dan Pendidikan Pancasila dan Kewarganegaraan adalah jurusan dengan tingkat pengetahuan tertinggi yaitu $65,57 \%$. Sedang jurusan Pendidikan Olahraga yang terdiri dari Program Studi Pendidikan Jasmani dan Rekreasi serta Kepelatihan adalah jurusan dengan tingkat pengetahuan terendah yaitu $63,21 \%$. Namun secara keseluruhan, pengetahuan keuangan mahasiswa dari enam belas program studi yang ada di Fakultas Keguruan dan Ilmu Pendidikan berada pada kategori literate.

Argumentasi yang digunakan untuk menjelaskan logika tidak signifikannya perbedaan tingkat pengetahuan keuangan mahasiswa ditinjau dari jurusan masih terkait dengan pengalaman. Pengalaman sebagaimana telah dijelaskan sebelumnya memberikan pengaruh terhadap pengetahuan seseorang. Pengalaman yang terkait dengan interaksi mahasiswa dengan instrumen keuangan sering terjadi saat mahasiswa melakukan transaksi pembelian atau pembayaran. Seluruh mahasiswa dari berbagai jurusan yang berbeda dengan penghasilan yang relatif sama maka akan memiliki jenis transaksi yang tidak jauh berbeda.

Mahasiswa penerima beasiswa Bidikmisi memiliki penghasilan yang relatif sama, sehingga akses transaksinya pun relatif sama sehingga menghasilkan pengalaman yang relatif sama pula. Aspek pengalaman yang diperoleh dengan interaksi mahasiswa dengan instrumen keuangan memang menjadi hal yang disinyalir membentuk pengetahuan keuangan mahasiswa. Hal ini dibuktikan dengan rendahnya pengetahuan mahasiswa terkait dengan rendahnya pengetahuan tentang investasi dan tabungan serta manajemen risiko.

Mahasiswa memiliki pengetahuan yang rendah dalam kedua aspek tersebut dikarenakan memang jarang melakukan bahkan tidak pernah sama sekali melakukan transaksi untuk menyimpan uang, melakukan investasi, dan kepemilikan asuransi. Mahasiswa Universitas Riau Penerima Beasiswa Bidikmisi banyak menghabiskan sumber daya keuangan yang dimilikinya untuk melakukan konsumsi, bukan tabungan, investasi, maupun asuransi. Hal ini dibuktikan dengan penelitian Sandra (2017) yang menemukan bahwa tingkat pendapatan mempengaruhi pola perilaku konsumsi sebesar $5,2 \%$, artinya, sekalipun pendapatan rendah, perilaku konsumsi tidak bias terkontrol dengan baik. Pada saat penelitian ditemukan beberapa mahasiswa membeli kebutuhan non prioritas.

Jika dianalisis secara deskriptif, sebenarnya terdapat perbedaan antara beberapa jurusan dalam hal pengetahuan keuangannya. Namun memang perbedaannya tidak begitu signifikan. Jurusan IImu Pendidikan Sosial menjadi jurusan yang paling tinggi pengetahuan keuangannya dengan persentase jawaban benar mencapai 65,57\%, sedangkan jurusan Pendidikan Olah Raga paling rendah persentase jawaban benarnya yaitu $63,21 \%$.

\section{Pengetahuan Keuangan Berdasarkan Level IPK}

Indeks Prestasi Kumulatif adalah satuan hasil belajar mahasiswa. IPK memiliki rentangan dari 0 sampai dengan 4. Dalam penelitian ini, IPK dijadikan acuan untuk pengukuran kemampuan kognitif. Beberapa kajian sebelumnya telah menemukan bahwa kemampuan kognitif seseorang mempengaruhi tingkat pengetahuan keuangannya. Mahasiswa Bidikmisi dituntut untuk memiliki IPK 2,9 bagai mahasiswa jurusan sains dan teknologi, dan minimal IPK 2,75 bagi mahasiswa jurusan Sosial dan Humaniora. Pengetahuan keuangan mahasiswa Fakultas Keguruan dan IImu Pendidikan Universitas Riau berdasar IPK disajikan pada Gambar 6. 


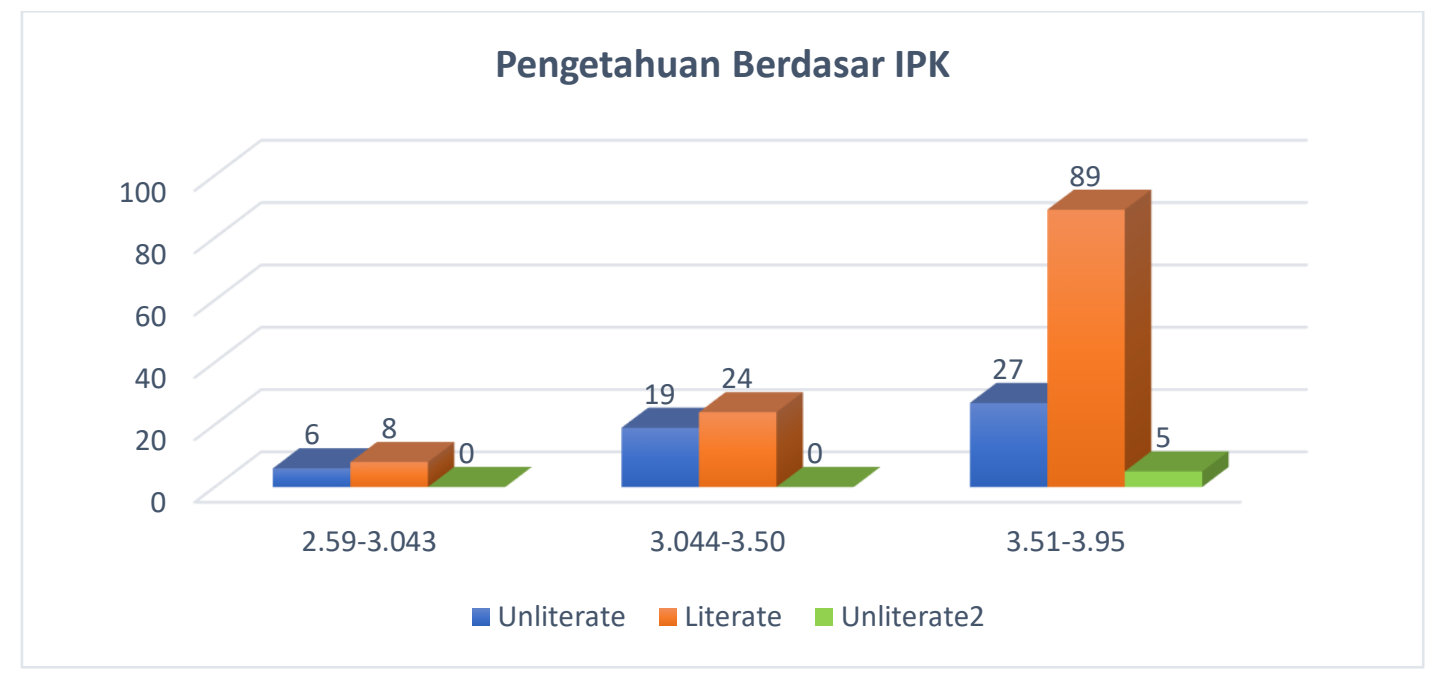

Gambar 6. Pengetahuan Keuangan Berdasarkan Indeks Prestasi Kumulatif

Indeks Prestasi Kumulatif mahasiswa FKIP Universitas Riau dikategorikan dalam tiga level. Level paling rendah adalah mahasiswa dengan IPK di antara 2,59 sampai 3,04, pada level ini 42,85\% mahasiswa memiliki pengetahuan keuangan pada kategori unliterate, sedangkan 57,15\% lainnya memiliki pengetahuan keuangan pada kategori literate. Mahasiswa pada level selanjutnya adalah yang memiliki IPK 3,04 sampai 3,5, pada level ini 44,18\% mahasiswa memiliki pengetahuan keuangan pada kategori unliterate, dan sebanyak $55,81 \%$ berada pada kategori literate.

Level tertinggi IPK pada level 3 adalah mahasiswa dengan IPK 3,51 sampai 3,95 , pada level ini $22,31 \%$ memiliki pengetahuan pada kategori unliterate, $73,55 \%$ memiliki pengetahuan pada kategori literate, dan 4,13\% memiliki pengetahuan pada kategori well literate. Secara keseluruhan, mahasiswa dengan IPK berada pada level 1 tingkat pengetahuannya berada pada kategori unliterate dengan persentase jawaban benar 59\%, mahasiswa dengan IPK berada peda level 2 tingkat pengetahuan keuangannya berada pada kategori literate dengan persentase jawaban benar $61 \%$, dan mahasiswa yang memiliki IPK level 3 pengetahuan keuangannya berada pada kategori literate dengan persentae jawaban benar $66,5 \%$.

\section{KESIMPULAN}

1. Tingkat literasi keuangan mahasiswa penerima beasiswa Bidikmisi Fakultas Keguruan dan IImu Pendidikan berada ada kategori literate dengan persentase jawaban benar $64,61 \%$.

2. Pengetahuan Keuangan mahasiswa perempuan berada pada kategori yang sama dengan mahasiswa laki-laki, yaitu pada kategori literate. Namun jika dilihat dari persentase jawaban benar, mahasiswa perempuan unggul dengan persentase jawaban benar $63,16 \%$ dibanding mahasiswa laki-laki yang persentase jawaban benarnya hanya $61,63 \%$.

3. Pengetahuan keuangan berdasarkan jurusan secara keseluruhan berada pada kategori literate. Jurusan Pendidikan IImu Pengetahuan Sosial persentase jawaban benarnya paling tinggi yaitu $65,57 \%$ dan jurusan Pendidikan Olah Raga persentase jawaban benarnya paling rendah yaitu $63,21 \%$.

4. Pengetahuan keuangan mahasiswa dengan IPK level $1(2,59-3,04)$ berada pada kategori unliterate, IPK level $2(3,04-3,5)$ dan IPK Level $3(3,5-3,95)$ berada pada kategori literate. 


\section{DAFTAR PUSTAKA}

Huston, S.J. 2010. Measuring financial literacy. The Journal of Consumer Affairs 44(2): 296-312. https://doi.org/10.1111/j.1745-6606.2010.01170.x

Irman, M. 2018. Analisis Faktor-faktor yang Mempengaruhi Financial Literacy di Kalangan Mahasiswa Universitas Muhammadiyah Riau (UMRI) Pekanbaru. Journal of Economic, Bussiness and Accounting (COSTING) 1(2): 180-197. https://doi.org/10.31539/costing.v1i2.205

Margaretha, F., dan R.A. Pambudhi. 2015. Tingkat Literasi Keuangan pada Mahasiswa S1 Fakultas Ekonomi. Jurnal Manajemen Dan Kewirausahaan 17(1): 76-85. https://doi.org/10.9744/jmk.17.1.76-85

Mawo, T., P. Thomas, dan S. Sunarto. 2017. Pengaruh Literasi Keuangan, Konsep Diri dan Budaya terhadap Perilaku Konsumtif Siswa SMAN 1 Kota Bajawa. Journal of Economic Education 6(1): 60-65.

Nababan, D., dan I. Sadalia. 2012. Analisis Personal Financial Literacy and Financial Behavior Mahasiswa Strata I Fakultas Ekonomi Universitas Sumatera Utara. Tesis. Universitas Sumatera Utara: Fakultas Ekonomi.

Organization for Economic Cooperation and Development. 2012. Measuring Financial Literacy. Working Paper. Paris: OECD.

Organization for Economic Cooperation and Development. 2014. Results: Students and Money: Financial Literacy Skills for the 21st Century (Volume VI). PISA. OECD Publishing.

Otoritas Jasa Keuangan. 2014. Literasi, Edukasi, dan Inklusi Keuangan. Jakarta: Direktorat Literasi dan Edukasi.

Remund, D.L. 2010. Financial literacy explicated: The case for a clear definition in an increasingly complex economy. The Journal of Consumer Affairs 44(2), 276-295. https://doi.org/10.1111/j.1745-6606.2010.01169.x

Rita, M.R., dan B.C.P. Pesudo. 2014. Apakah Mahasiswa Sudah Melek Keuangan?. Jurnal Dinamika Akuntansi, Keuangan dan Perbankan 3(1): 58-65.

Sandra, M. 2017. Pola Perilaku Konsumsi Mahasiswa Bidikmisi 2013. JOM FISIP 4(2): 1-14.

Syahza, A. 2014. Metodologi Penelitian. Pekanbaru: UR Press.

Tsalitsa, A. 2016. Analisis Pengaruh literasi Keuangan dan faktor Demografi terhadap Pengambilan Kredit pada PT. Columbia Cabang Kudus. Media Ekonomi dan Manajemen 31(1): 1-13.

Widayati, I. 2012. Faktor-faktor yang Mempengaruhi Literasi Finansial Mahasiswa Fakultas Ekonomi dan Bisnis Universitas Brawijaya. ASSET: Journal Akuntansi dan Pendidikan 1(1): 89-99. https://doi.org/10.25273/jap.v1i1.527

Woodyard, A., and C. Robb. 2012. Financial Knowledge and the Gender Gap. Journal of Financial Therapy 3(1): 1-16. https://doi.org/10.4148/ift.v3i1.1453 